Journal of

(C) All rights are reserved by Ortanca et al.

\section{"Not Guilty by Reason of Insanity": Common Characteristics in Six Homicide Cases from Hatay, Turkey}

Keywords: NG RI; Insanity; Homic ide; Filic ide; Hatay; Turkey

\begin{abstract}
Background: Not guilty by reason of insanity is a court verdict, meaning the defendant is not responsible for the crime because of his or her mental illness. In this artic le we aim to describe six not guilty by reason of insanity judged homic ide cases in our province and discuss their features which are globally common.
\end{abstract}

Methods: We collected data from the crime court records of the Hatay province in Turkey concluded between 2009 and 2013 (both years included).

Results: Five of the victims were blood relatives and one wa the spouse of the perpetrator. All victims were co-living with the perpetrator. None of the perpetrators used firearms. Three victims were children killed by their mothers.

Conclusion: Not guilty by the reason insanity is a specific and rare judgement in criminal courts, whereas there are some characteristic which a re universally common and predominant.

\section{Introduction}

Not guilty by reason of insanity (NGRI) is a verdict issued in criminal cases whereby the defendant, is not held responsible for his or her criminal actions. The presence of mental illness is a necessity for the legal determinations of insanity. On the other hand the defendant might have a medically defined psychological disorder but still not be insane. Since it is a legal condition the defendant is evaluated by forensic mental health professionals with the appropriate tests according to the jurisdiction before the court's decision [1]. Article 32 in the Turkish Criminal Code says: "A person lacking ability to perceive the legal meaning and consequences of the offense, or having considerably lost the capacity to control his actions due to insanity may not be subject to any punishment. However, security precautions are imposed for such individuals [2]. In Turkey, the decision is given according to the expert witness report of a committee of forensic psychiatrists and forensic medicine specialists who evaluates the defendant for several weeks in a health care institution.

Although NGRI verdict is not specific to any crime, it becomes more important in case of homicide, for judgment authorities, the case parties and also forensic mental health professionals. Today there are many studies on the associations between homicide and mental illnesses [3-6]. Most of the academic research and discussions on insanity defence are about homicides [7-11]. Therefore mental evaluation of a homicide defendant is a critical issue for forensic psychiatrists and forensic medicine specialists. Since NGRI is an uncommon verdict, even small series may constitute valuable information for experts. Our aim is to describe the six NGRI judged

\section{Forensic Investigation}

\begin{abstract}
Ibrahim Ortanca ${ }^{1 *}$, Mehmet Hanifi Kokacya ${ }^{2}$, Adnan Çelikel ${ }^{1}$, Sumeyra Demirkiran ${ }^{1}$, Cem Zeren $^{1}$
\end{abstract} and M. Mustafa Arslan ${ }^{1}$

${ }^{1}$ Department of Forensic Medicine, Faculty of Medicine, Mustafa Kemal University, Hatay, Turkey

${ }^{2}$ Department of Psychiatry, Faculty of Medicine, Mustafa Kemal University, Hatay, Turkey

Address for Correspondence

Ibrahim Ortanca, Department of Forensic Medicine, Faculty

of Medicine, Mustafa Kemal University, 31120 Hatay, Turkey, E-mail: ortanca.ibrahim@gmail.com

Submission: 16 August, 2014

Accepted: 31 November, 2014

Published: 02 December, 2014

homicide cases in our province and discuss their common properties in reference to international literature.

\section{Material and Methods}

We collected our data retrospectively from the reasoned judgement records of criminal courts of Hatay a province of Turkey which were concluded between 2009 and 2013 both years included. Therefore the homicides were not necessarily committed in this period; but rather the courts gave their final decision. A total of 83 homicide cases were concluded in the period. Six verdicts (of total number of verdicts) were NGRI which were taken into the scope of this study. The psychiatric diagnoses had been made at a forensic psychiatric evaluation by psychiatrists and forensic medicine specialists after the crime.

\section{Results}

There were three male and three female victims between 2 months and 54 years of age. Three of five perpetrators were female and two of them were male. Median age of perpetrators was 27 (19-66). Details about age and genders, relation between victim and perpetrator, cause of death, place and description of the event, history of mental illness, treatment and documented diagnosis after psychiatric evaluation for each case are presented in Table 1.

\section{Discussion}

There are remarkable points that are common. In all of our cases, we see that the victim is a blood relative or spouse of the perpetrator. Besides one victim who stayed with the offender (his father) in regular periods although he has his own house, all victims shared the same houses with their killers. In a study in which 1136 psychiatric patients discharged from mental institutions were followed, violence was mostly documented to be targeted against family members or friends and mostly take place at home [12]. In another study comparing (a) people who committed homicide and judged NGRI versus (b) people who were convicted murderers, the insanity acquittees were more likely to be seen as psychotic at the time of the index offense, 
Citation: Ortanca I, Kokacya MH, Çelikel A, Demirkiran S, Zeren C, et al. "Not Guilty by Reason of Insanity": Common Characteristics in Six Homicide Cases from Hatay, Turkey. J Forensic Investigation. 2014;2(4): 3.

ISSN: 2330-0396

Table 1: Individual details of NGRI cases.

\begin{tabular}{|c|c|c|c|c|c|c|c|c|c|}
\hline \multicolumn{2}{|c|}{ Victim info. } & \multicolumn{3}{|c|}{ Offender Information } & \multirow{2}{*}{$\begin{array}{c}\text { Cause } \\
\text { of death }\end{array}$} & \multirow{2}{*}{ Place } & \multirow{2}{*}{ Description of the Event and Reasons } & \multirow{2}{*}{$\begin{array}{c}\text { History of Mental IIIness } \\
\text { and Treatment }\end{array}$} & \multirow{2}{*}{$\begin{array}{l}\text { Documented } \\
\text { diagnosis }\end{array}$} \\
\hline Sex & Age & Sex & Age & Relation & & & & & \\
\hline Male & 38 years & Male & 66 years & $\begin{array}{c}\text { Father of } \\
\text { victim }\end{array}$ & $\begin{array}{l}\text { Sharp } \\
\text { force } \\
\text { injury }\end{array}$ & $\begin{array}{c}\text { House of } \\
\text { the offender }\end{array}$ & $\begin{array}{l}\text { Son came to his father's house to provide } \\
\text { care. While the son was sleeping after } \\
\text { finishing some house works, his father } \\
\text { stabbed him } 13 \text { times. }\end{array}$ & $\begin{array}{c}\text { According to a neighbour, } \\
\text { theperpetrator wasin } \\
\text { psychiatric treatment and he } \\
\text { suffered from mood swings: } \\
\text { sometimes calm, sometimes } \\
\text { nervous. According to the } \\
\text { wife of the victim, her father } \\
\text { in law was mentally ill and } \\
\text { her husband used to take } \\
\text { care of him. }\end{array}$ & $\begin{array}{l}\text { Paranoid } \\
\text { psychosis }\end{array}$ \\
\hline Female & 54 years & Male & 53 years & $\begin{array}{l}\text { Husband } \\
\text { of victim }\end{array}$ & $\begin{array}{l}\text { Head } \\
\text { trauma. } \\
\text { and- } \\
\text { sharp } \\
\text { force } \\
\text { injury }\end{array}$ & Field & $\begin{array}{l}\text { The perpetrator had thoughts about } \\
\text { his wife cheating on him with their son. } \\
\text { First, he hit her head with an iron steak. } \\
\text { After she fell down he hit her head with } \\
\text { a stone and stabbed her with a knife. } \\
\text { The perpetrator stated in court the he " } \\
\text { warned her several times about cheating } \\
\text { me, but she continued" }\end{array}$ & $\begin{array}{l}\text { A few years prior to the } \\
\text { incident the perpetrator } \\
\text { had lost one eye in an } \\
\text { occupational accident. His } \\
\text { children stated "His mental } \\
\text { health started to change after } \\
\text { the accident and worsened } \\
\text { with time, our mother never } \\
\text { cheated him" }\end{array}$ & $\begin{array}{l}\text { Paranoid } \\
\text { psychosis }\end{array}$ \\
\hline Female & 28 years & Female & 19 years & $\begin{array}{l}\text { Sister of } \\
\text { victim }\end{array}$ & $\begin{array}{l}\text { Sharp } \\
\text { force } \\
\text { injury }\end{array}$ & $\begin{array}{l}\text { Home of } \\
\text { both the } \\
\text { perpetrator } \\
\text { and the } \\
\text { victim }\end{array}$ & $\begin{array}{l}\text { The perpetrator stated that her elder } \\
\text { sister slandered about her sleeping with } \\
\text { the husband of one of their other sisters. } \\
\text { Therefore the perpetrator and her elder } \\
\text { sister argued, fought and the perpetrator } \\
\text { stabbed her elder sister in her leg. The } \\
\text { perpetrator stated that she didn't intend } \\
\text { to kill, but to wound. }\end{array}$ & $\begin{array}{l}\text { The perpetrator says, } \\
\text { she is using medicine } \\
\text { for psychiatric treatment. } \\
\text { Father stated both the } \\
\text { sisters were diagnosed with } \\
\text { schizophrenia. }\end{array}$ & Schizophrenia \\
\hline Male & 2 months & Female & 27 years & $\begin{array}{c}\text { Mother of } \\
\text { victim }\end{array}$ & $\begin{array}{l}\text { Blunt } \\
\text { force } \\
\text { trauma }\end{array}$ & $\begin{array}{l}\text { House they } \\
\text { live together }\end{array}$ & $\begin{array}{l}\text { The mother woke up early in the morning } \\
\text { to feed the baby and walked to the room } \\
\text { where her husband and older child } \\
\text { were sleeping. She wished her husband } \\
\text { farewell and jumped from window with } \\
\text { her son. The baby died because of head } \\
\text { trauma, the mother sustained a broken } \\
\text { leg and liver laceration. }\end{array}$ & $\begin{array}{c}\text { Before the woman gave } \\
\text { birth, the family moved to a } \\
\text { new city in which she was } \\
\text { unhappy. While she was } \\
\text { speaking with her mother } \\
\text { on phone, she mentioned } \\
\text { symptoms of headaches, } \\
\text { tingling and tremor on } \\
\text { her hands. After thebirth } \\
\text { psychiatric medicine was } \\
\text { prescribed to her but } \\
\text { she didn't use it regularly } \\
\text { because she was breast } \\
\text { feeding. }\end{array}$ & $\begin{array}{l}\text { Acute } \\
\text { psychotic } \\
\text { disorder }\end{array}$ \\
\hline Female & 1 year & & & & & & & Her friends had noticed & \\
\hline Male & 4 years & Female & 21 years & $\begin{array}{c}\text { Mother of } \\
\text { victims }\end{array}$ & $\begin{array}{l}\text { As- } \\
\text { phyxia }\end{array}$ & $\begin{array}{l}\text { House they } \\
\text { live together }\end{array}$ & $\begin{array}{l}\text { The mother first had tried to cut her son's } \\
\text { ankles. He had resisted and she killed } \\
\text { him and her daughter by smothering. } \\
\text { Afterwards she tried to hang herself in } \\
\text { the bathroom but she couldn't. Instead } \\
\text { she climbed to the roof with the intention } \\
\text { of jumping, but neighbours saw her and } \\
\text { stopped her. }\end{array}$ & $\begin{array}{c}\text { personality changes since } \\
\text { she gave birth to her second } \\
\text { child. She was in a pensive } \\
\text { mood, doing disproportionate } \\
\text { house cleaning, talking about } \\
\text { suicide and seemed addicted } \\
\text { to her children. She had } \\
\text { been receiving psychiatric } \\
\text { treatment for } 3 \text { months prior } \\
\text { to the killing. Her husband } \\
\text { was frequently abroad be- } \\
\text { cause of his job. }\end{array}$ & $\begin{array}{l}\text { Depression } \\
\text { with psychotic } \\
\text { feature }\end{array}$ \\
\hline
\end{tabular}

and also were more likely to have killed their blood relatives [13]. None of the perpetrators used firearms in our group. According to a large group (n: 620) of homicidal autopsy series in Turkey 55\% of the victims are killed by firearms [14]. The number is $74 \%$ in America and $21 \%$ on average in Europe [15]. We believe a possible explanation for this discrepancy in weapons used in NGRI and non-NGRI cases could be that killing a person with a firearm often needs intention and planning, especially in countries where obtaining a fire arm is not easy.
Three cases of filicides committed by two young mothers are noticeable in our group. It is a significant cause of child mortality in many societies including wealthy industrialized nations [16-19]. Both our cases are associated with suicide. Resnick, who first classified child murders in 1969 put "filicide associated with suicide" under the classification of "altruistic filicides" [20]. In two cases there are similarities in testimonies of friends and relatives on the mother who committed the homicide. Psychiatric changes first appeared following the birth of their children. We know that postpartum 
Citation: Ortanca I, Kokacya MH, Çelikel A, Demirkiran S, Zeren C, et al. "Not Guilty by Reason of Insanity": Common Characteristics in Six Homicide Cases from Hatay, Turkey. J Forensic Investigation. 2014;2(4): 3.

depression and other postpartum mood disorders are important public health problems universally [21-25]. In our sample, symptoms were serious enough to cause both women to see a psychiatrist and medication was initiated. A recent study of filicides showed that $40 \%$ of perpetrators, mostly mothers rather than fathers, had a history of mental health problems [26]. Another study showed both parents are equally likely to be convicted of a homicide offence; however fathers were more likely to be jailed than mothers for committing filicide [17]. According to our samples, women are more prone to commit filicide under the effect of mental illness, so they are more likely to be judged as not guilty for the reason of insanity.

For a few decades, a similar verdict called "Guilty but Mentally Ill (GBMI)" has been issued in some American states GBMI means that, the defendant is guilty of an offense and was mentally ill at the time of that offense. However, the defendant was not legally insane at the time of the offense [27]. Although the GBMI verdict is allowed in only a minority of American states, it receives substantial press coverage and is the subject of much controversy [28,29]. Even though the GBMI verdict is not eligible in Turkey, if it were, in our opinion; those 6 cases would be judged legally insane at the time of their offense.

\section{Conclusion}

We have evaluated six cases of homicides committed by five people who were judged NGRI. All victims were blood relatives of the perpetrators except one, who was the wife of the perpetrator. All victims were sharing the same house with his or her perpetrator except one, who however stayed with his father (the perpetrator) for longer periods of time. None of the homicides were committed by firearm. Three child killing events committed by two mothers drew our attention to postpartum mental mood disorders of women. There were no men in our group who committed filicide.

\section{References}

1. CR Williams (2003) Not Guilty By Reason of Insanity (NGRI) in Encyclopedia of Murder and Violent Crime, E. Hickey, Ed. Thousand Oaks: Sage Publications Inc

2. Turkish Criminal Code (2011) Law No. 5237 of September 26, 2004, as last amended by Law No. 6217

3. G Cote, S Hodgins (1992) The prevalence of major mental disorders among homicide offenders. Int J Law Psychiatry 15: 89-99.

4. M Eronen, P Hakola, J Tiihonen (1996) Mental disorders and homicidal behavior in Finland. Arch Gen Psychiatry 53: 497-501.

5. S. Richard-Devantoy, JP Olie, R Gourevitch (2009) Risk of homicide and major mental disorders: a critical review. Encephale 35: 521-530.

6. H Schanda, G Knecht, D Schreinzer, T Stompe, G Ortwein-Swoboda, et al (2004) Homicide and major mental disorders: a 25-year study. Acta Psychiatr Scand 110: 98-107.

7. J Ferranti, BE McDermott, CL Scott (2013) Characteristics of female homicide offenders found not guilty by reason of insanity. J Am Acad Psychiatry Law 41:516-522.

8. J Feix, G Wolber (2007) Intoxication and settled insanity: a finding of not guilty
9. M Yoo, M Guyer (2009) NGRI Acquittals. J Am Acad Psychiatry Law 37: 124 127.

10. SH Friedman, DR Hrouda, CE Holden, SG Noffsinger, PJ Resnick (2005) Child Murder Committed by Severely Mentally III Mothers: An Examination of Mothers Found Not Guilty By Reason of Insanity. J Forensic Sci 50:14661471.

11. IK Packer (1987) Homicide and the insanity defense: A comparison of sane and insane murderers. Behav Sci Law 5: 25-35.

12. HJ Steadman, EP Mulvey, J Monahan, PC Robbins, PS Appelbaum, et al. (1998) Violence by People Discharged From Acute Psychiatric Inpatient Facilities and by Others in the Same Neighborhoods. Arch Gen Psychiatry 55: 393-401.

13. PG Nestor, J Haycock (1997) Not guilty by reason of insanity of murder: clinical and neuropsychological characteristics. J Am Acad Psychiatry Law 25: 161-171.

14. A Hilal, N Çekin, MK Gülmen, MH Özdemir, R Karanfil (2005) Homicide in Adana, Turkey: A 5-year review. Am J Forensic Med Pathol 26: 141-145.

15. J Gibbons Ed (2011) Global Study on Homicide. Vienna: Unıted Natıons Offıce on Drugs and Crıme.

16. J Jason, JC Gilliland, CW Tyler (1983) Homicide as a cause of pediatric mortality in the United States. Pediatrics 72: 191-197.

17. MN Marks, R Kumar (1993) Infanticide in England and Wales. Med Sci Law 33: 329-339.

18. T Sakuta, S Saito (1981) A socio-medical study on 71 cases of infanticide in Japan. Keio J Med 30: 155-168.

19. LKH Somander, LM Rammer (1991) Intra- and extrafamilial child homicide in Sweden 1971-1980. Child Abus Negl 15: 45-55.

20. PJ Resnick (1969) Child murder by parents: a psychiatric review of filicide. Am J Psychiatry 126: 325-334.

21. AM Rhodes, LS Segre (2013) Perinatal depression: a review of US legislation and law. Arch Womens Ment Health 16: 259-270.

22. M Karakus, H Ince, N Ince, N Arican, S Sozen (2003) Filicide cases in Turkey, 1995-2000. Croat Med J 44: 592-595.

23. Taguchi $H$ (2007) Maternal filicide in Japan: analyses of 96 cases and future directions for prevention. Seishin Shinkeigaku Zasshi 109: 110-127.

24. MK Krischer, MH Stone, K Sevecke, EM Steinmeyer (2007) Motives for maternal filicide: results from a study with female forensic patients. Int J Law Psychiatry 30: 191-200.

25. AIF Simpson, J Stanton (2000) Maternal filicide: A reformulation of factors relevant to risk. Crim Behav Ment Heal 10: 136-147.

26. SM Flynn, JJ Shaw, KM Abel (2013) Filicide: mental illness in those who kill their children. PLoS One 8: e58981.

27. A Robey (1978) Guilty But Mentally III. Bull Am Acad Psychiatry Law 6: $374-$ 381.

28. J Kutys, J Esterman (2009) Guilty but Mentally III ( GBMI ) vs Not Guilty by Reason of Insanity ( NGRI ): An Annotated Bibliography. Jury Expert 21: 2837.

29. J Melville, D Naimark (2002) Punishing the insane: the verdict of guilty but mentally ill. J Am Acad Psychiatry Law 30: 553-555.

\section{Acknowledgements}

Copyright: () 2014 Ortanca I, et al. This is an open access article distributed under the Creative Commons Attribution License, which permits unrestricted use, distribution, and reproduction in any medium, provided the original work is properly cited.
This study was poster presented in IAFS 2014, Seoul, Korea on October 12-18, 2014. 